\title{
Mean birth weight among term newborns: direction, magnitude and associated factors
}

\section{Média de peso ao nascer em recém-nascidos a termo: direção, magnitude e fatores associados}

\section{Peso medio al nacer entre recién nacidos a término: tendencia, magnitud y factores asociados}

Antônio Augusto Moura da Silva 1

Carolina Abreu de Carvalho 1,2

Heloisa Bettiol 3

Marcelo Z. Goldani 4

Fernando Lamy Filho 1

Zeni Carvalho Lamy 1

Marlos R. Domingues 4

Viviane C. Cardoso 3

Ricardo de C. Cavalli 3

Bernardo Lessa Horta 5

Aluisio J. D. Barros 5

Marco Antonio Barbieri 3

doi: 10.1590/0102-311X00099419

\begin{abstract}
A trend towards increasing birth weight has been shown, but factors that explain these trends have not been elucidated. The objectives of this study were to evaluate changes in mean birth weight of term newborns and to identify factors associated with them. All cohorts are population-based studies in which random samples of births (Ribeirão Preto, São Paulo State in 1978/1979, 1994 and 2010; Pelotas, Rio Grande do Sul State in 1982, 1993 and 2004; and São Luís, Maranhão State in 1997/1998 and 2010, Brazil). A total of 32,147 full-term, singleton live births were included. Mean birth weight reduced in the first study period (-89.1g in Ribeirão Preto from 1978/1979 to 1994, and -27.7g in Pelotas from 1982 to 1993) and increased $+30.2 \mathrm{~g}$ in Ribeirão Preto from 1994 to 2010 and +24.7g in São Luís from 1997 to 2010. In the first period, in Ribeirão Preto, mean birth weight reduction was steeper among mothers with high school education and among those born 39-41 weeks. In the second period, the increase in mean birth weight was steeper among mothers with low schooling in Ribeirão Preto and São Luis, females and those born 37-38 weeks in Ribeirão Preto and cesarean section in São Luís. Birth weight decreased in the first study period then increased thereafter. The variables that seem to have been able to explain these changes varied over time.
\end{abstract}

Birth Weight; Term Birth; Newborn Infant; Socioeconomic Factors

\author{
Correspondence \\ C. A. Carvalho \\ Universidade Federal do Maranhão. \\ R. Barão de Itapari 155, São Luís, MA 65020-070, Brasil. \\ carolcarvalho91@gmail.com \\ 1 Universidade Federal do Maranhão, São Luís, Brasil. \\ 2 Instituto Federal do Maranhão, Barreirinhas, Brasil. \\ 3 Universidade de São Paulo, São Paulo, Brasil. \\ 4 Universidade Federal do Rio Grande do Sul, Porto Alegre, \\ Brasil. \\ 5 Universidade Federal de Pelotas, Pelotas, Brasil.
}




\section{Background}

Birth weight is associated with severe neonatal morbidity and perinatal mortality ${ }^{1}$. In addition, it has also been linked to the occurrence of chronic diseases in adult life 2 . There are two factors that can decrease birth weight: reduction in gestational age and/or increase in intrauterine growth restriction 3 .

Studies of time trends in birth weight in high-income countries point that birth weight increased at the end of the last century, despite increasing preterm birth rate in some settings 4,5,6,7,8. However, more recently, it seems that this upward trend is being reversed and reductions in birth weight have been documented in many countries 9,10,11,12. This decrease has been described even among full-term infants, indicating a possible reversal of the increasing trend in mean birth weight 13 . These trends are not universal and diverge between countries and even within the same country. Factors that explain these trends still have not been completely elucidated.

There is some evidence that most of this decrease might have been due to reduction in gestational duration and increases in preterm and early term birth rates 10,14. However, in some settings, fetal growth has also declined independently of gestational age at birth and the reasons for this decline in fetal growth are poorly understood 9,15,16. It has been suggested that maternal, health service and socioeconomic factors would explain changes in mean birth weight 10,11,13.

Few studies were performed in low and middle-income countries. Mean birth weight also decreased in China 17. In Brazil, a reduction of 122g in mean birth weight from 1978/1979 to 1994 was observed in Ribeirão Preto, São Paulo State 18; even among children born by vaginal delivery, the decrease was of $101 \mathrm{~g} 19$. A reduction of $47 \mathrm{~g}$ was also observed in Pelotas, Rio Grande do Sul State, from 1982 to 2004 20. We did not find any Brazilian study evaluating changes in birth weight including in only term newborns.

It is well known that preterm birth leads to reduced birth weight due to shortening of pregnancy duration 21. However, little is known about the contribution of fetal growth to birth weight among term newborns, especially in low and middle-income countries. Moreover, it is necessary to investigate the influence of different factors on trends in mean birth weight, especially in cities with different socioeconomic levels and medical technology incorporation. So, the aim of this manuscript is to evaluate changes in mean birth weight of term newborns, using data from eight birth cohorts from three cities located in different regions of Brazil - Ribeirão Preto, São Luís and Pelotas - and to identify factors associated with these changes.

\section{Methods}

This study used data from eight birth cohorts carried out in three Brazilian cities: Ribeirão Preto, Pelotas and São Luís, from 1978 to 2010. Multiple pregnancies, missing gestational age or gestational age lower than 37 weeks or greater than 42 weeks were excluded.

Ribeirão Preto is a city located in São Paulo state, southeastern Brazil. This city is one of the most developed in Brazil, with annual per capita income of USD 4,505.28 and human development index (HDI) of 0.800 in 2010. In Ribeirão Preto three birth cohorts were assembled in the years 1978/1979, 1994 and 2010. The 1978/1979 birth cohort evaluated 6,831 singleton live births, delivered at the eight existing hospitals in Ribeirão Preto from June 1st, 1978 to May 31st, 1979, representing 98\% of all births in the city during that period. The second birth cohort (1994) evaluated all live births from all ten public and private hospitals for a sample of four consecutive months (April 25th to August 25th, 1994), a total of 2,858 singleton live births were evaluated. In 2010, a third birth cohort was assembled in Ribeirão Preto, including all births that occurred at all hospitals in the city. A total of 7,754 live births from resident mothers were included from January 1st to December 31st, 2010. The non-response rate, due to early hospital discharge or refusal, was 3.5\% in 1978/1978, 4.2\% in 1994 and $3.8 \%$ in 2010. Only singleton term live births were included, resulting in 5,977 observations for analysis in 1978/1979, 2,370 in 1994 and 6,129 in 2010. More detailed information about the methods of the Ribeirão Preto birth cohorts were published elsewhere 22.

São Luís, the capital of Maranhão State, is located in northeastern Brazil, one of the poorest regions in the country. In 2010, the city had HDI of 0.768 and an annual per capita income of USD 
2,761.23. In 1997/1998, the city's first birth cohort was carried out, from March 1st, 1997 to February 28th, 1998, in all maternity hospitals that attended more than 100 births per year. In 2010, a second birth cohort was assembled in all city hospitals with more than 100 births per year from January 1 st to December 31st, 2010. A total of 2,443 singleton live births were evaluated in 1997/1998 and 5,067 in 2010. Losses accounted for $5.8 \%$ of cases in $1997 / 1998$ and $4.6 \%$ in 2010 . For this analysis, only term singleton live births were included, resulting in 1,969 births in 1997/1998 and 4,059 in 2010. Details of the study methods were published elsewhere 22,23.

The city of Pelotas is located in Southern Brazil. The city's HDI is 0.739 and the annual per capita income is USD 3,066.37. Three birth cohorts were followed-up in the city, starting in 1982, 1993 and 2004, all with similar recruitment strategies. From January 1st to December 31st of each year, all maternity hospitals were visited daily aiming to recruit all liveborns to mothers who lived in the urban area of the city. The number of live births in each cohort was 5,914 in 1982, 5,249 in 1993 and 4,231 in 2004. The refusal rate for all cohorts was less than $1 \%$. For this analysis, only term singleton live births were included, totaling 3,861 in 1982, 4,520 in 1993 and 3,262 in 2004. More information on the methods used in these three cohorts is available elsewhere 24.

In all eight cohorts, information was obtained through questionnaires answered by the mothers regarding socioeconomic, health service, reproductive, lifestyle and demographic variables. Birth weight was measured using analog scales with precision of $10 \mathrm{~g}$ in Ribeirão Preto in 1978/1979 and 1994, in Pelotas in 1982, and in São Luís in 1997/1998. Digital scales with precision of $5 \mathrm{~g}$ were used in Ribeirão Preto and São Luís in 2010 and with 10g in Pelotas in 1993 and 2004.

The variables analyzed were: birth weight (continuous - in grams), maternal age $(<20,20-34$, and $\geq 35$ years), maternal education ( $0-4,5-8,9-11$, and $\geq 12$ years), marital status (with or without a partner), parity, including the current delivery $(1,2-4, \geq 5)$, adequacy of prenatal care visits (at least six attendances), maternal smoking during pregnancy (yes or no), type of delivery (vaginal or caesarean) and sex of the newborn. Gestational age was estimated according to the last normal menstrual period in Ribeirão Preto in 1978/1979 and 1994, Pelotas in 1982, and São Luís in 1997/1998 and 2010. In Pelotas 1993 and 2004, gestational age was calculated by the best obstetric estimate, based primarily on ultrasound, and secondarily on the last normal menstrual period. In Ribeirão Preto 2010, two criteria were employed to estimate gestational age: the first criterion took into account the date of the last normal menstrual period reported by the mother and the second used an algorithm that was based on the date of the last normal menstrual period and on the obstetric ultrasonography if it was available. Missing data on gestational age were imputed in a linear regression model using birth weight, parity, family income and sex as predictors 25 for Ribeirão Preto and São Luís birth cohorts. Gestational age was categorized into $37-38$ or $39-41$ weeks.

Statistical analyses were performed with Stata (https://www.stata.com). The chi-square test was used to compare proportions. Means of birth weight and differences between mean birth weight over the years and their $95 \%$ confidence intervals $(95 \% \mathrm{CI})$ were calculated.

Initially we ran a model containing all cohorts together. Interactions between year (continuous) and city (categorical) and a quadratic term for year were tested. Since interactions between year and city were highly significant we ran separate models for each city and furthermore only two birth cohorts were compared at a time because of nonlinearities (the quadratic term was significant).

To analyze factors that would possibly account for trends in mean birth weight over time an indicator variable called "year" was created to measure the "year effect" in each of the cities. For example, for Ribeirão Preto an indicator variable "year" was coded 0 for the year 1978/1979 and 1 for 1994. Thus, results for this variable contain information regarding differences in birth weight between these two time periods. To compare data from the 1994 with the 2010 Ribeirão Preto birth cohort, another indicator variable was created, coded as 0 for 1994 and 1 for 2010. For the other two cities, Pelotas and São Luís, similar indicator variables were created.

Factors that would possibly account for changes in mean birth weight over time were then included in sequential multiple linear regression models following a hierarchical approach (Figure 1). Initially a crude time effect was calculated regressing birth weight on the indicator variable year (Model 1). Then, in Model 2, adjustment was performed for year, maternal schooling and sex, because maternal schooling influences all other variables and the inclusion of mediating variables of maternal schooling (e.g. maternal age or smoking) on birth weight in this model could mitigate 
Figure 1

Hierarchical theoretical model to assess changes in mean birth weight over time.

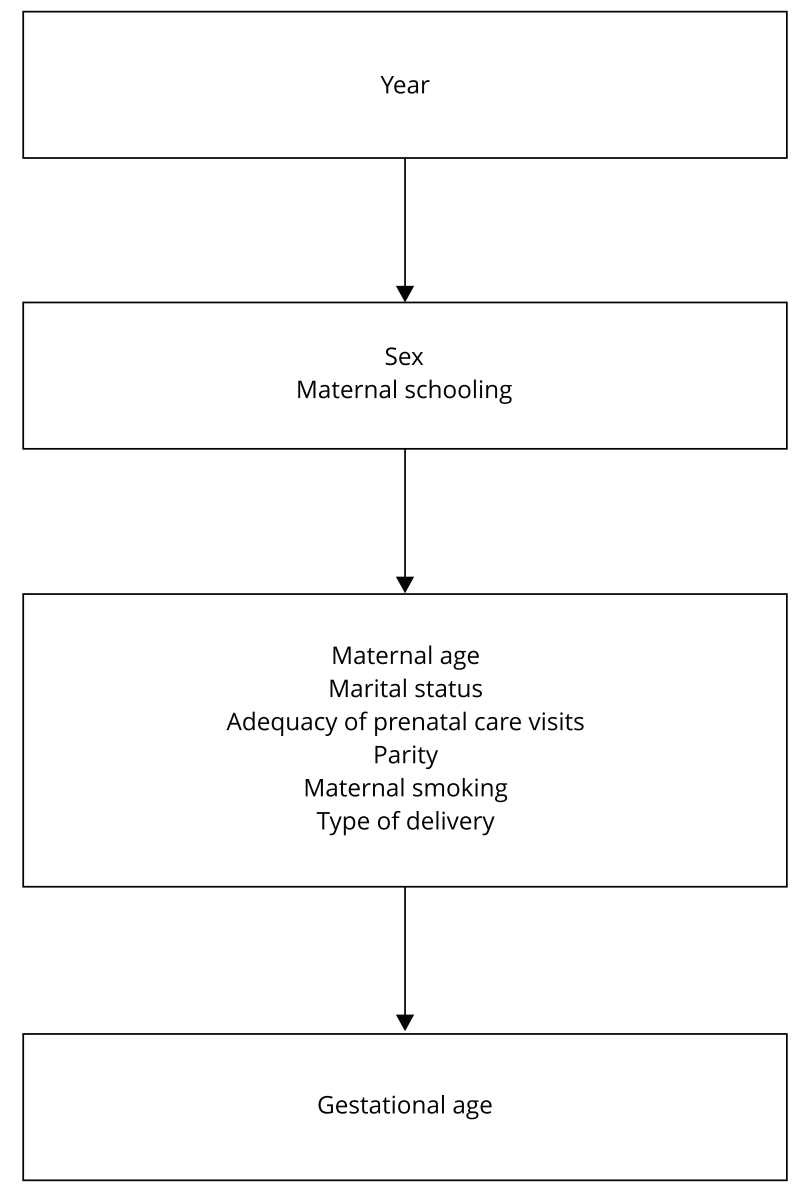

the "true effect" of schooling. Next, Model 3 was adjusted for maternal age, marital status, adequacy of prenatal care visits, parity, maternal smoking during pregnancy and type of delivery plus year, maternal schooling and sex. And finally, in Model 4 adjustment was performed for all those variables plus gestational age.

Interactions between the indicator variable "year" and maternal schooling and sex were tested in Model 2. Interactions between maternal age, marital status, parity, maternal smoking during pregnancy and type of delivery and the indicator variable "year" were tested in Model 3. And finally, interactions between gestational age and the indicator variable "year" were tested in Model 4. Interactions were tested to determine if the effect of each variable was different for each year and thus if each variable would be able to explain changes in birth weight over time. Significance level for interaction was set at 0.10 . For all other analysis the significance level was 0.05 . The margins command was used to estimate changes in mean birth weight according to maternal, socioeconomic, health service and demographic characteristics, taking interactions and confounding into account.

For the older cohorts (Ribeirão Preto, 1978/1979 and 1994; Pelotas, 1982 and 1993; and São Luís, 1997/1998) we obtained the approval of an Internal Committee of the respective Schools of Medicine and verbal informed maternal consent. All other cohorts were approved by the Research Ethics Com- 
mittees of the teaching institutions to which they were linked and the mothers gave written informed consent before interview.

\section{Results}

The supplementary Tables 1 and 2 (http://cadernos.ensp.fiocruz.br/site/public_site/arquivo/supplcsp-0994-19_9550.pdf) present changes in variables that may influence birth weight. Maternal age was increased in all cities. Maternal smoking and parity were reduced in all comparisons except in Pelotas from 1982 to 1993. Maternal schooling and caesarean delivery increased in all three cities, except in Pelotas from 1982 to 1993 where the maternal schooling was reduced in the category over 12 years of study and the caesarean delivery did not change. Gestational age of 37-38 weeks rose in Ribeirão Preto, from 1978/1979 to 1994; Pelotas, from 1982 to 1993; and São Luís, from 1997/1998 to 2010, but decreased in Pelotas, from 1993 to 2004; and did not change in Ribeirão Preto, from 1994 to 2010.

\section{Ribeirão Preto}

Mean birth weight reduced by 89.1g (95\%CI: -111.0; -67.2) from 3,297g in 1978/79 to 3,208g in 1994 in Ribeirão Preto (Table 1). After adjustment for confounding and considering two significant interactions of year with maternal schooling and gestational age, the reduction in Mean birth weight was lower for infants born to mothers with schooling $\leq 4$ years $(-96 \mathrm{~g})$ and between 5 and 8 years $(-88 \mathrm{~g})$ compared to mothers with intermediate $(-120 \mathrm{~g})$ or high school education $(-161 \mathrm{~g})$ in a model also adjusted for sex. Those born 39-41 weeks of gestational age presented greater reduction in mean birth weight $(-114 \mathrm{~g})$ than those born 37-38 weeks (-48g) (Table 2).

From 1994 to 2010, there was an increase in mean birth weight of 30.2g (95\%CI: 9.5; 50.8), from 3,208g to 3,238g in Ribeirão Preto (Table 1). After adjustment for confounding and considering three significant interactions of year with maternal schooling, sex and gestational age, the increase in mean birth weight was higher for children of mothers with lower schooling $\leq 4$ years $(+80 \mathrm{~g})$ compared to the other maternal schooling groups. In addition, mean birth weight increased $42 \mathrm{~g}$ among girls. Those born 39-41 weeks of gestational age presented a $18 \mathrm{~g}$ reduction in mean birth weight whereas those born 37-38 weeks showed a $+50 \mathrm{~g}$ increase in mean birth weight (Table 2).

\section{Pelotas}

In Pelotas, mean birth weight decreased 27.7g (95\%CI: -47.7; -7.7) from 3,283g in 1982 to $3.255 \mathrm{~g}$ in 1993 (Table 1). After adjustment for confounding and taking into account a significant interaction between year and type of delivery, those born vaginally presented birth weight $37 \mathrm{~g}$ lower in 1993 than in 1982. Despite this reduction in birth weight, cesarean delivery was a contributing factor to children born $3 \mathrm{~g}$ heavier (Table 2).

In Pelotas, from 1993 to 2004, overall mean birth weight did not change (6.7g, 95\%CI: -13.9; 27.4) (data not shown). Therefore, this cohort was not included in the adjusted analysis.

\section{São Luís}

In São Luís, mean birth weight increased 24.7g (95\%CI: 0.1; 49.2) from 3,242g in 1997/1998 to $3.266 \mathrm{~g}$ in 2010 (Table 1). After adjustment for confounding and taking into account one significant interaction between year and maternal schooling, this increase was explained by the higher mean birth weight among children of mothers with low schooling and born by cesarean section. Those born to mothers with low schooling (< 4 years) were $86 \mathrm{~g}$ heavier in 2010 compared to those born in 1997 , whereas those born to mothers with high school education ( $\geq 12$ years) were $56 \mathrm{~g}$ lighter at birth in 2010 than those born in 1997 . Those born vaginally in 2010 were $24 \mathrm{~g}$ leaner whereas those born by cesarean were $46 \mathrm{~g}$ heavier in 2010 compared to their counterparts born in 1997 (Table 2). 


\section{Table 1}

Sequential linear regression model of changes in mean birth weight. Ribeirão Preto, São Paulo State 1978/1979 to 1994 and 1994 to 2010 ; Pelotas, Rio Grande do Sul State 1982 to 1993; and São Luís, Maranhão State 1997/1998 to 2010, Brazil.

\begin{tabular}{|c|c|c|c|c|}
\hline Characteristics * & $\begin{array}{c}\text { Ribeirão Preto } \\
1978 / 1979 \text { to } 1994 \\
\text { Coefficient }(95 \% \mathrm{Cl})\end{array}$ & $\begin{array}{c}\text { Ribeirão Preto } \\
1994 \text { to } 2010 \\
\text { Coefficient }(95 \% \mathrm{Cl})\end{array}$ & $\begin{array}{c}\text { Pelotas } \\
1982 \text { to } 1993 \\
\text { Coefficient }(95 \% \mathrm{Cl})\end{array}$ & $\begin{array}{c}\text { São Luís } \\
1997 / 1998 \text { to } 2010 \\
\text { Coefficient }(95 \% \mathrm{Cl})\end{array}$ \\
\hline \multicolumn{5}{|l|}{ Model 1} \\
\hline Year & $-89.1(-111.0 ;-67.2)$ & $30.2(9.5 ; 50.8)$ & $-27.7(-47.7 ;-7.7)$ & $24.7(0.1 ; 49.2)$ \\
\hline \multicolumn{5}{|l|}{ Model 2} \\
\hline Year & $-160.6(-221.7 ;-99.5)$ & $20.8(-35.3 ; 76.9)$ & $-21.6(-41.6 ;-1.7)$ & $-55.7(-151.5 ; 40.1)$ \\
\hline \multicolumn{5}{|c|}{ Maternal schooling (years) } \\
\hline$\geq 12$ & Reference & Reference & Reference & Reference \\
\hline $9-11$ & $-58.0(-105.5 ;-10.4)$ & $-17.0(-77.0 ; 43.0)$ & $-16.8(-54.8 ; 21.2)$ & $-87.2(-182.4 ; 8.1)$ \\
\hline $5-8$ & $-123.2(-165.9 ;-80.5)$ & $-50.4(-105.5 ; 4.7)$ & $-101.3(-133.1 ;-69.4)$ & $-105.6(-199.9 ;-11.3)$ \\
\hline$\leq 4$ & $-142.5(-181.8 ;-103.1)$ & $-76.3(-136.2 ;-16.3)$ & $-118.4(-152.2 ;-84.6)$ & $-115.2(-216.6 ;-13.9)$ \\
\hline \multicolumn{5}{|l|}{ Sex } \\
\hline Female & Reference & Reference & Reference & Reference \\
\hline Male & $136.8(116.9 ; 156.7)$ & $163.8(127.8 ; 199.8)$ & $123.2(103.5 ; 142.9)$ & $94.9(71.8 ; 117.9)$ \\
\hline \multicolumn{5}{|l|}{ Interactions } \\
\hline \multicolumn{5}{|c|}{ Maternal schooling (years) $X$ year } \\
\hline$\geq 12$ & Reference & Reference & ** & Reference \\
\hline $9-11$ & $40.3(-38.9 ; 119.5)$ & $14.6(-51.1 ; 80.3)$ & ** & $78.6(-24.5 ; 181.8)$ \\
\hline $5-8$ & $72.7(0.5 ; 144.9)$ & $29.9(-34.0 ; 93.7)$ & ** & $68.8(-36.3 ; 173.8)$ \\
\hline$\leq 4$ & $65.2(-9.3 ; 139.7)$ & $81.4(-3.9 ; 166.7)$ & & $142.0(13.5 ; 270.5)$ \\
\hline \multicolumn{5}{|l|}{ Sex $X$ year } \\
\hline Female & $* *$ & Reference & ** & ** \\
\hline Male & ** & $-45.2(-87.3 ;-3.1)$ & ** & ** \\
\hline \multicolumn{5}{|l|}{ Model 3} \\
\hline Year & $-204.7(-269.0 ;-140.5)$ & $25.8(-32.8 ; 84.4)$ & $-30.3(-66.6 ; 6.0)$ & $-89.0(-194.5 ; 16.5)$ \\
\hline \multicolumn{5}{|c|}{ Adequacy of prenatal care visits } \\
\hline Adequate & Reference & Reference & Reference & Reference \\
\hline Inadequate & $-44.3(-67.8 ;-20.9)$ & $-58.9(-92.5 ;-25.3)$ & $-37.6(-70.9 ;-4.2)$ & $-20.8(-46.7 ; 5.1)$ \\
\hline \multicolumn{5}{|l|}{ Maternal age (years) } \\
\hline $20-34$ & Reference & Reference & Reference & Reference \\
\hline$\geq 35$ & $-41.6(-82.2 ;-1.1)$ & $-20.8(-51.9 ; 10.2)$ & $-12.2(-63.1 ; 38.7)$ & $-0.9(-50.0 ; 48.1)$ \\
\hline$<20$ & $-64.8(-97.2 ;-32.3)$ & $-32.4(-63.6 ;-1.1)$ & $-89.1(-134.1 ;-44.2)$ & $-17.9(-49.9 ; 14.1)$ \\
\hline \multicolumn{5}{|l|}{ Marital status } \\
\hline Cohabiting & Reference & Reference & Reference & Reference \\
\hline Without a partner & $-43.7(-83.0 ;-4.3)$ & $-4.1(-33.8 ; 25.6)$ & $-17.7(-74.4 ; 39.1)$ & $-21.1(-50.7 ; 8.6)$ \\
\hline \multicolumn{5}{|l|}{ Parity } \\
\hline $2-4$ & Reference & Reference & Reference & Reference \\
\hline 1 & $-42.4(-66.3 ;-18.4)$ & $-80.4(-101.9 ;-58.9)$ & $-64.5(-97.3 ;-31.6)$ & $-118.7(-144.6 ;-92.8)$ \\
\hline$\geq 5$ & $77.9(37.5 ; 118.3)$ & $102.6(44.7 ; 160.4)$ & $50.9(0.7 ; 101.1)$ & $141.0(73.6 ; 208.5)$ \\
\hline \multicolumn{5}{|l|}{ Maternal smoking } \\
\hline No & Reference & Reference & Reference & Reference \\
\hline Yes & $-159.6(-183.6 ;-135.6)$ & $-161.6(-191.2 ;-131.9)$ & $-171.6(-202.0 ;-141.3)$ & $-65.1(-123.2 ;-7.0)$ \\
\hline \multicolumn{5}{|l|}{ Type of delivery } \\
\hline Vaginal & Reference & Reference & Reference & Reference \\
\hline Cesarean & $61.3(38.4 ; 84.2)$ & $19.5(-1.7 ; 40.7)$ & $48.9(16.8 ; 81.0)$ & $44.7(-0.1 ; 89.6)$ \\
\hline
\end{tabular}

(continues) 
Table 1 (continued)

\begin{tabular}{|c|c|c|c|c|}
\hline Characteristics * & $\begin{array}{c}\text { Ribeirão Preto } \\
1978 / 1979 \text { to } 1994 \\
\text { Coefficient }(95 \% \mathrm{Cl})\end{array}$ & $\begin{array}{c}\text { Ribeirão Preto } \\
1994 \text { to } 2010 \\
\text { Coefficient }(95 \% \mathrm{Cl})\end{array}$ & $\begin{array}{c}\text { Pelotas } \\
1982 \text { to } 1993 \\
\text { Coefficient }(95 \% \mathrm{Cl})\end{array}$ & $\begin{array}{c}\text { São Luís } \\
\text { 1997/1998 to } 2010 \\
\text { Coefficient }(95 \% \mathrm{Cl})\end{array}$ \\
\hline \multicolumn{5}{|l|}{ Interactions } \\
\hline \multicolumn{5}{|c|}{ Type of delivery $X$ year } \\
\hline Vaginal & ** & ** & Reference & Reference \\
\hline Cesarean & ** & ** & $40.3(-2.9 ; 83.6)$ & $70.0(16.0 ; 123.9)$ \\
\hline \multicolumn{5}{|l|}{ Model 4} \\
\hline Year & $-72.7(-137.2 ;-8.3)$ & $70.2(9.4 ; 131.0)$ & $2.8(-20.7 ; 26.4)$ & $-79.5(-182.8 ; 23.7)$ \\
\hline \multicolumn{5}{|c|}{ Gestational age (weeks) } \\
\hline $37-38$ & Reference & Reference & Reference & Reference \\
\hline $39-41$ & $322.9(297.5 ; 348.4)$ & $259.9(222.8 ; 297.1)$ & $146.7(126.5 ; 166.8)$ & $191.9(168.1 ; 215.6)$ \\
\hline \multicolumn{5}{|l|}{ Interactions } \\
\hline \multicolumn{5}{|c|}{ Gestational age (weeks) $X$ year } \\
\hline $37-38$ & Reference & Reference & $* *$ & ** \\
\hline $39-41$ & $-65.3(-111.1 ;-19.4)$ & $-68.5(-111.6 ;-25.4)$ & ** & ** \\
\hline
\end{tabular}

Model 1: birth weight and year.

Model 2: birth weight, year, maternal schooling and sex.

Model 3: birth weight, year, maternal schooling, sex, maternal age, maternal status, parity, maternal smoking and type of delivery.

Model 4: birth weight, year, maternal schooling, sex, maternal age, maternal status, parity, maternal smoking, type of delivery and gestational age.

* The variables of the next level are adjusted for the variables of the previous level(s). However, the coefficients of the variables of the previous levels were omitted.

** There was no interaction between the variable and the year in this cohort.

\section{Table 2}

Changes in mean birth weight (g) according to maternal schooling, type of delivery, sex or gestational age. Ribeirão Preto, São Paulo State 1978/1979 to 1994 and 1994 to 2010; Pelotas, Rio Grande do Sul State 1982 to 1993; and São Luís, Maranhão State 1997 to 2010, Brazil.

\begin{tabular}{|c|c|c|c|c|c|c|c|c|c|c|c|c|}
\hline \multirow[t]{2}{*}{ Characteristics } & \multicolumn{6}{|c|}{ Ribeirão Preto } & \multicolumn{3}{|c|}{ Pelotas } & \multicolumn{3}{|c|}{ São Luís } \\
\hline & 1978/1979 & 1994 & Dif. & 1994 & 2010 & Dif. & 1982 & 1993 & Dif. & 1997/1998 & 2010 & Dif. \\
\hline Total & 3,297 & 3,208 & -89 & 3,208 & 3,238 & +30 & 3,283 & 3,255 & -28 & 3,242 & 3,266 & -24 \\
\hline \multicolumn{13}{|c|}{ Maternal schooling (years) } \\
\hline$\geq 12$ & 3,409 & 3,248 & -161 & 3,246 & 3,244 & -2 & * & * & * & 3,335 & 3,279 & -56 \\
\hline $9-11$ & 3,351 & 3,231 & -120 & 3,229 & 3,242 & +13 & * & * & * & 3,248 & 3,271 & +23 \\
\hline $5-8$ & 3,286 & 3,198 & -88 & 3,196 & 3,224 & +28 & * & * & * & 3,229 & 3,243 & +14 \\
\hline$\leq 4$ & 3,267 & 3,171 & -96 & 3,170 & 3,250 & +80 & * & * & * & 3,220 & 3,306 & +86 \\
\hline \multicolumn{13}{|l|}{ Type of delivery } \\
\hline Vaginal & * & * & * & * & * & * & 3,267 & 3,230 & -37 & 3,235 & 3,211 & -24 \\
\hline Cesarean & * & * & * & * & * & * & 3,316 & 3,319 & +3 & 3,280 & 3,326 & +46 \\
\hline \multicolumn{13}{|l|}{ Sex } \\
\hline Female & * & * & * & 3,138 & 3,180 & +42 & * & * & * & * & * & * \\
\hline Male & * & * & * & 3,301 & 3,298 & -3 & * & * & * & * & * & * \\
\hline \multicolumn{13}{|c|}{ Gestational age (weeks) } \\
\hline $37-38$ & 3,081 & 3,033 & -48 & 3,076 & 3,126 & +50 & * & * & * & * & * & * \\
\hline $39-41$ & 3,404 & 3,290 & -114 & 3,336 & 3,318 & -18 & * & * & * & * & * & * \\
\hline
\end{tabular}

Dif.: adjusted difference between the years according to each variable considering interactions.

* There was no interaction with this variable in this year. 


\section{Discussion}

Trends in mean birth weight among term births varied over time. Mean birth weight reduced in the first study period (Ribeirão Preto, from 1978/1979 to 1994; and Pelotas, from 1982 to 1993) and increased in more recent times (Ribeirão Preto, from 1994 to 2010; and São Luís, from 1997 to 2010). However, it did not change in Pelotas, from 1993 to 2004. Apart from these diverging trends over different time periods, the variables that seem to have been able to explain these trends in multivariable models varied over time.

Birth weight is influenced by fetal growth and gestational age 3 . In the first study periods, mean birth weight dropped when analyzing only term newborns, thus excluding the influence preterm birth might have had on birth weight. High maternal education, cesarean section and gestational age from 39-41 weeks seem to explain the reduction in mean birth weight in Ribeirão Preto, but only vaginal delivery seems to explain this decline in Pelotas.

Increasing medical interventions have been shown to be associated with reduced mean birth weight 18 and with a shift to the left in the birth weight distribution in Ribeirão Preto 26. It was also associated to increasing detection of fetal growth restriction followed by cesarean section. In its turn, cesarean section was associated with increased low birth weight and intrauterine growth restriction rates 27 but reduced stillbirth and infant mortality rates 28 among all births, including preterm and term. However, in Pelotas cesarean section does not seem to explain birth weight reductions. Instead, reduced mean birth weight seems to be explained by vaginal delivery.

The largest reduction in birth weight in newborns of highly educated mothers ( $\geq 12$ years) in Ribeirão Preto (1978/1979-1994), may have been influenced by increased access to medical intervention in this group, especially to cesarean section 29,30 . This led to a reduction of social inequality related to adverse perinatal outcomes in the same period reported for this cohort 31 . Our results indicate that even when analyzing only children born at term there was a reduction in social inequality in mean birth weight. This reduction of social inequality however was obtained due to a worsening of the mean birth weight in the groups with higher education.

The increased birth weight in recent years occurred despite a decrease in mean gestational age in all cities, indicating that in this period the rise in birth weight was due to increased fetal growth. The increasing birth weight in recent years verified in Brazilian cities in the 1990s are consistent with improvements in socioeconomic and regional disparities, health service coverage, maternal education and in prenatal and childbirth care use, as well as reduction in income inequality at this time ${ }^{32}$. In this study maternal education consistently contributed to explain a portion of the increase in mean birth weight in São Luís and in Ribeirão Preto in the more recent period.

In the second study period there seems to be a positive effect of education on birth weight among the most disadvantaged. The increase in birth weight was higher among mothers with less than four years of schooling. Noronha et al. 30 also documented an increase in mean birth weight among less educated mothers. These results highlight the consequences of advances in prenatal and childbirth care, as they are practically universal in Brazil in recent years 32,33.

In São Luís, cesarean section also seems to explain the increased mean birth weight. It is possible that increased availability of early ultrasound to date pregnancy more accurately and increased awareness of the possible risks of preterm birth due to scheduled elective cesarean sections are contributing to the postponement of surgical births to more advanced gestational ages. It possibly led to improvements in birth weight among term births. High weight fetuses tend to have indication for cesarean delivery, which may also help explain the increased weight of term newborns delivered by cesarean.

Interestingly, gestational age among term deliveries seems to have influenced mean birth weight only in the city of Ribeirão Preto and its effect seems to have changed throughout the years. In the first period, reduction in mean birth weight was steeper among those born 39-41 weeks of gestational age but in the second period mean birth weight increased more sharply among those born 37-38 weeks of gestational age. Thus gestational age among term birth may have contributed to a reduction of mean birth weight in the first period and to a rise in mean birth weight in the second period.

The three evaluated towns have different socioeconomic levels. Ribeirão Preto is one of the cities with the highest HDI in the country. São Luís is the capital of one of the poorest Brazilian states. Pelotas, although located in a state with high socioeconomic development, has an HDI slightly lower 
than that of São Luís. These cities also have different levels of availability to health technology, which is higher in Ribeirão Preto. Despite these differences in socioeconomic indicators and incorporation of health technology, birth weight trends seem to have been similar across cities.

Some variables that were not included in this analysis because they were not available for all cohorts could have had some influence on the average birth weight. Pre-gestational body mass index (BMI) and weight gain during pregnancy have been reported in the literature as factors that may affect the birth weight of the baby. Mothers who gain more weight than recommended during pregnancy have a higher risk of having babies with macrosomia, and those who gain less weight than recommended have a higher risk of having small for gestational age babies 34. A systematic review showed that women with low birth weight in the pre-gestation or early pregnancy period were more likely to have low birth weight or preterm infants 35 .

This has limitations such as the absence of some variables that could have influenced birth weight such as pre-pregnancy BMI and induction of labor. The birth weight measurement method changed over time between cohorts: in some of them, digital scales were used and in others, analog scales. This may have influenced average birth weight. Another limitation is the method used for estimating gestational age, which varied between the cohorts. It has been described that last normal menstrual period tend to overestimate gestational age 36,37 . Nevertheless, other studies also pointed out that last normal menstrual period may provide a good estimate for calculating gestational age, although its use is not recommended for making clinical decisions such as elective cesarean sections 38 .

However, it stands out as key strengths for this study the use of data from eight birth cohorts held in three different Brazilian cities and located in regions with different socioeconomic characteristics. In addition, all cohorts are population-based studies in which random samples of births or all births in the cities were included. Percentages of losses in the eight cohorts were low and the methods used for data abstraction in the eight cohorts were similar.

\section{Conclusions}

In conclusion, birth weight decreased in the first study period and increased thereafter in three Brazilian cities located in different regions. Decreases in mean birth weight in the first period seem to be due to higher maternal schooling and 39-41 weeks of gestational age in Ribeirão Preto and to vaginal delivery in Pelotas. Increases in mean birth weight in the second period seem to be explained by low maternal schooling in Ribeirão Preto and São Luís, by cesarean section in São Luís and by female sex and 37-38 weeks of gestational age in Ribeirão Preto. 


\section{Contributors}

A. A. M. Silva made substantial contributions to the conception and design, acquisition of data, analysis and interpretation of data, drafted the article, revised the article critically for important intellectual content, and approved the final version to be published. C. A. Carvalho made substantial contributions to the analysis and interpretation of data, drafted the article, revised the article critically for important intellectual content, and approved the final version to be published. H. Bettiol, B. L. Horta, A. J. D. Barros and M. A. Barbieri made substantial contributions to the conception and design, acquisition of data, analysis and interpretation of data, revised the article critically for important intellectual content and approved the final version to be published. M. Z. Goldani, F. Lamy Filho, Z. C. Lamy, M. R. Domingues, V. C. Cardoso and R. C. Cavalli made substantial contributions to the analysis and interpretation of data, revised the article critically for important intellectual content, and approved the final version to be published.

\section{Additional informations}

ORCID: Antônio Augusto Moura da Silva (00000003-4968-5138); Carolina Abreu de Carvalho (0000-0001-7900-4642); Heloísa Bettiol (00000001-8744-4373); Marcelo Z. Goldani (0000-00025302-284X); Fernando Lamy Filho (0000-00027858-4195); Zeny Carvalho Lamy (0000-00029332-0542); Marlos R. Domingues (0000-00022503-2944); Viviane C. Cardoso (0000-0002-26775600); Ricardo de C. Cavalli (0000-0001-50104914); Bernardo Lessa Horta (0000-0001-9843412X); Aluisio J. D. Barros (0000-0002-2022-8729); Marco Antonio Barbieri (0000-0001-8060-1428).

\section{Acknowledgments}

We thank all mothers and babies who participated in these cohort studies. We also thank the funding agencies that funded these studies.

\section{References}

1. Class QA, Rickert ME, Lichtenstein P, D'Onofrio BM. Birth weight, physical morbidity, and mortality: a population-based sibling-comparison study. Am J Epidemiol 2014; 179:550-8.

2. Zhang Z, Kris-Etherton PM, Hartman TJ. Birth weight and risk factors for cardiovascular disease and type 2 diabetes in US children and adolescents: 10 year results from NHANES. Matern Child Health J 2014; 18:1423-32.

3. McCowan LM, Figueras F, Anderson NH. Evidence-based national guidelines for the management of suspected fetal growth restriction: comparison, consensus, and controversy. Am J Obstet Gynecol 2018; 218:S855-S68.

4. Kramer MS, Morin I, Yang H, Platt RW, Usher $\mathrm{R}, \mathrm{McNamara} \mathrm{H}$, et al. Why are babies getting bigger? Temporal trends in fetal growth and its determinants. J Pediatr 2002; 141:538-42.

5. Wen SW, Kramer MS, Platt R, Demissie K, Joseph KS, Liu S, et al. Secular trends of fetal growth in Canada, 1981 to 1997. Paediatr Perinat Epidemiol 2003; 17:347-54.

6. Power C. National trends in birth weight: implications for future adult disease. BMJ 1994; 308:1270-1.

7. Alberman E. Are our babies becoming bigger? J R Soc Med 1991; 84:257-60.

8. Ghosh RE, Berild JD, Sterrantino AF, Toledano MB, Hansell AL. Birth weight trends in England and Wales (1986-2012): babies are getting heavier. Arch Dis Child Fetal Neonatal Ed 2018; 103:F264-F70.

9. Morisaki N, Esplin MS, Varner MW, Henry E, Oken E. Declines in birth weight and fetal growth independent of gestational length. Obstet Gynecol 2013; 121:51-8.

10. Terada M, Matsuda Y, Ogawa M, Matsui $\mathrm{H}$, Satoh S. Effects of maternal factors on birth weight in Japan. J Pregnancy 2013; 2013:172395.

11. He JR, Li WD, Lu MS, Guo Y, Chan FF, Lu JH, et al. Birth weight changes in a major city under rapid socioeconomic transition in China. Sci Rep 2017; 7:1031.

12. Kim HE, Song IG, Chung SH, Choi YS, Bae $\mathrm{CW}$. Trends in birth weight and the incidence of low birth weight and advanced maternal age in Korea between 1993 and 2016. J Korean Med Sci 2019; 34:e34.

13. Donahue SM, Kleinman KP, Gillman MW, Oken E. Trends in birth weight and gestational length among singleton term births in the United States: 1990-2005. Obstet Gynecol 2010; 115:357-64.

14. Zhang X, Joseph KS, Kramer MS. Decreased term and postterm birthweight in the United States: impact of labor induction. Am J Obstet Gynecol 2010; 203:124 e1-7.

15. Oken E. Secular trends in birthweight. Nestle Nutrition Institute Workshop Series 2013; 71:103-14. 
16. Agay-Shay K, Rudolf M, Rubin L, Haklai Z, Grotto I. Trends in fetal growth between 2000 to 2014 in singleton live births from Israel. Sci Rep 2018; 8:1089.

17. Guo Y, Liu Y, He JR, Xia XY, Mo WJ, Wang P, et al. Changes in birth weight between 2002 and 2012 in Guangzhou, China. PLoS One 2014; 9:e115703.

18. Silva AA, Barbieri MA, Bettiol H, Goldani MZ, Rona RJ. Can we explain why Brazilian babies are becoming lighter? Int J Epidemiol 2004; 33:821-8.

19. Barbieri MA, Silva AA, Bettiol H, Gomes UA. Risk factors for the increasing trend in low birth weight among live births born by vaginal delivery, Brazil. Rev Saúde Pública 2000; 34:596-602.

20. Barros FC, Victora CG, Barros AJ, Santos IS, Albernaz E, Matijasevich A, et al. The challenge of reducing neonatal mortality in middle-income countries: findings from three Brazilian birth cohorts in 1982, 1993, and 2004. Lancet 2005; 365:847-54.

21. Blencowe H, Krasevec J, Onis M, Black RE, An X, Stevens GA, et al. National, regional, and worldwide estimates of low birthweight in 2015, with trends from 2000: a systematic analysis. Lancet Glob Health 2019; 7:e849-e60.

22. Cardoso VC, Simoes VM, Barbieri MA, Silva AA, Bettiol H, Alves MT, et al. Profile of three Brazilian birth cohort studies in Ribeirao Preto, SP and São Luis, MA. Braz J Med Biol Res 2007; 40:1165-76.

23. Silva AAM, Batista RFL, Simões VMF, Thomaz EBAF, Ribeiro CCC, Lamy Filho F, et al. Changes in perinatal health in two birth cohorts (1997/1998 and 2010) in São Luís, Maranhão State, Brazil. Cad Saúde Pública 2015; 31:1437-50.

24. Barros AJD, Santos IS, Matijasevich A, Araújo CL, Gigante DP, Menezes AMB, et al. Methods used in the 1982, 1993, and 2004 birth cohort studies from Pelotas, Rio Grande do Sul State, Brazil, and a description of the socioeconomic conditions of participants' families. Cad Saúde Pública 2008; 24 Suppl 3:S371-80.

25. Little RJA, Rubin DB. Statistical analysis with missing data. 2nd Ed. New Jersey: John Wiley \& Sons; 2002.

26. Silva AA, Barbieri MA, Gomes UA, Bettiol H. Trends in low birth weight: a comparison of two birth cohorts separated by a 15 -year interval in Ribeirao Preto, Brazil. Bull World Health Organ 1998; 76:73-84.

27. Chen Y, Wu L, Zhang W, Zou L, Li G, Fan L. Delivery modes and pregnancy outcomes of low birth weight infants in China. J Perinatol 2016; 36:41-6.
28. Molina G, Weiser TG, Lipsitz SR, Esquivel MM, Uribe-Leitz T, Azad T, et al. Relationship between cesarean delivery rate and maternal and neonatal mortality. JAMA 2015; 314:2263-70.

29. Mendoza-Sassi RA, Cesar JA, Silva PR, Denardin G, Rodrigues MM. Risk factors for cesarean section by category of health service. Rev Saúde Pública 2010; 44:80-9.

30. Noronha GA, Lima MC, Lira PI, Veras AA, Goncalves FC, Batista Filho M. Evolução da assistência materno-infantil e do peso ao nascer no Estado de Pernambuco em 1997 e 2006. Ciênc Saúde Colet 2012; 17:2749-56.

31. Lamy Filho F, Assuncao Junior AN, Silva AA, Lamy ZC, Barbieri MA, Bettiol H. Social inequality and perinatal health: comparison of three Brazilian cohorts. Braz J Med Biol Res 2007; 40:1177-86.

32. Victora CG, Aquino EM, do Carmo Leal M, Monteiro CA, Barros FC, Szwarcwald CL. Maternal and child health in Brazil: progress and challenges. Lancet 2011; 377:1863-76.

33. Barros AJD, Victora CG, Horta BL, Wehrmeister FC, Bassani D, Silveira MF, et al. Antenatal care and caesarean sections: trends and inequalities in four population-based birth cohorts in Pelotas, Brazil, 1982-2015. Int J Epidemiol 2019; 48:i37-i45.

34. Goldstein RF, Abell SK, Ranasinha S, Misso M, Boyle JA, Black MH, et al. Association of gestational weight gain with maternal and infant outcomes: a systematic review and meta-analysis. JAMA 2017; 317:2207-25.

35. Rahman MM, Abe SK, Kanda M, Narita S, Rahman MS, Bilano V, et al. Maternal body mass index and risk of birth and maternal health outcomes in low- and middle-income countries: a systematic review and meta-analysis. Obes Rev 2015; 16:758-70.

36. Aris IM, Kleinman KP, Belfort MB, Kaimal A, Oken E. A 2017 US reference for singleton birth weight percentiles using obstetric estimates of gestation. Pediatrics 2019; 144:e20190076.

37. Callaghan WM, Dietz PM. Differences in birth weight for gestational age distributions according to the measures used to assign gestational age. Am J Epidemiol 2010; 171:826-36.

38. Macaulay S, Buchmann EJ, Dunger DB, Norris SA. Reliability and validity of last menstrual period for gestational age estimation in a lowto-middle-income setting. J Obstet Gynaecol Res 2019; 45:217-25. 


\section{Resumo}

Existem evidências de uma tendência de aumento do peso ao nascer, mas pouco se sabe sobre os fatores que explicam essa tendência. Avaliar as mudanças na média de peso ao nascer e identificar os fatores associados. Foram incluidas todas as coortes de base populacional com amostras aleatórias de nascimentos (Ribeirão Preto, São Paulo em 1978/1979, 1994 e 2010; Pelotas, Rio Grande do Sul em 1982, 1993 e 2004; São Luís, Maranhão em 1997/1998 e 2010, Brasil). Foi incluido um total de 32.147 nascidos vivos a termo, de feto único. A média de peso ao nascer diminuiu no primeiro período estudado (-89, $1 \mathrm{~g}$ entre 1978/1979 e 1994 em Ribeirão Preto e -27,7g entre 1982 e 1993 em Pelotas) e aumentou no segundo período, $+30,2 \mathrm{~g}$ entre 1994 e 2010 em Ribeirão Preto e +24, $7 \mathrm{~g}$ entre 1997 e 2010 em São Luís. No primeiro período, em Ribeirão Preto, a redução na média de peso ao nascer foi maior entre mães com escolaridade mais alta e crianças nascidas com 39-41 semanas de idade gestacional. No segundo período, o aumento na média de peso ao nascer foi maior entre mães com escolaridade mais baixa em Ribeirão Preto e São Luís, crianças do sexo feminino e nascidas com 37-38 semanas em Ribeirão Preto e crianças nascidas de cesárea em São Luís. O peso ao nascer diminuiu no primeiro período e aumentou desde então. As variáveis que parecem explicar essas mudanças variaram ao longo do tempo.

Peso ao Nascer; Nascimento a Termo; Recém-Nascido; Fatores Socioeconômicos

\section{Resumen}

Se ha mostrado una tendencia de aumento de peso al nacer, pero los factores que explican esta tendencia todavía no han sido elucidados. Evaluar los cambios en el peso medio al nacer de los recién nacidos a término e identificar factores asociados. Se trata de un estudio de todas las cohortes basadas en población, donde existe una muestra aleatoria simple de nacimientos (Ribeirão Preto, São Paulo en 1978/1979, 1994 y 2010; Pelotas, Rio Grande do Sul en 1982, 1993 y 2004; y São Luís, Maranhão en 1997/1998 y 2010, Brasil). Se incluyeron un total de 32.147 de nacimientos a término completo con embarazo de un único feto. El peso medio al nacer se redujo en el primer estudio del período (-89, $1 \mathrm{~g}$ en Ribeirão Preto desde 1978/1979 a 1994 y -27,7g en Pelotas desde 1982 a 1993) y se incrementó $+30,2 \mathrm{~g}$ en Ribeirão Preto desde 1994 a $2010 y+24.7 g$ en São Luís desde 1997 a 2010. En el primer periodo, en Ribeirão Preto, la reducción del peso medio al nacer fue más pronunciada entre madres con una escolarización más alta y entre aquellos nacidos con 39-41 semanas. En el segundo período, el incremento en el peso medio al nacer fue más pronunciado entre las madres con una escolarización más baja en Ribeirão Preto y São Luis, mujeres y aquellos que nacieron con 37-38 semanas en Ribeirão Preto y en el área de cesáreas en São Luís. Disminuyó el peso al nacer durante el primer período de estudio y se vio incrementado después. Las variables que parecen capaces de explicar estos cambios varían a lo largo del tiempo.

Peso al Nacer; Nacimiento a Término; Recién Nacido; Factores Socioeconómicos
Submitted on 28/May/2019

Final version resubmitted on 02/Sep/2019

Approved on 06/Sep/2019 